\title{
O Ethos da Mulher V: \\ Consumo e construção da identidade feminina na Igreja Universal' 1 ,
}

\author{
Karla Patriota Bronsztein ${ }^{2}$ \\ Emanuelle Brandão Rodrihues 3
}

\begin{abstract}
Resumo: Este trabalho promove uma análise sobre a emergência de um ethos que se mostra como o alicerce da identidade feminina desejável dentro da Igreja Universal do Reino de Deus - IURD. Como objeto de análise, selecionamos um programa televisivo (The Love School) que se transformou numa poderosa marca de produtos e serviços da igreja e uma apresentadora (Cristiane Cardoso) que corporifica, pelo espírito empreendedor de seus discursos midiáticos de sucesso e felicidade, como a identidade da mulher ideal (por ela chamada de Mulher V) está relacionada ao consumo simbólico de produtos e serviços ligados à Igreja Universal. Palavras-chave: identidade; ethos; consumo; Igreja Universal do Reino de Deus; The Love School.
\end{abstract}

Abstract: This paper promotes an analysis over the emerging of an ethos as a foundation of the desirable femininy identity within the Universal Church of the Kingdom of God - UCKG. As a focal point, we have selected a television show (The Love School), that has shown itself as a powerful brand of products and services of the church, and one host (Cristiane Cardozo), that embodied, under the business spirit of hers midiaticspeechs about happiness and success, the ideal woman identity ("v woman", as by her called), related to the symbolic consumption of products and services linked to the Universal Church. Keywords: identity; ethos; consumption; Universal Church of the Kingdom of God; The Love School.

\section{Introdução}

A discussão em torno da questão da identidade no campo da comunicação tem assumido contornos diversos, demonstrando a fragilidade de conceitos essencialistas que outrora definiram a identidade como um projeto

${ }^{1}$ Este artigo é a versão ampliada de um texto apresentado no $4^{\mathrm{o}}$ Encontro de GTsComunicon, realizado nos dias 08, o9 e 10 de outubro de 2014, na ESPM.

2 Doutora em Sociologia, Mestre em Comunicação e Professora do Mestrado e Doutorado em Comunicação - PPGCOM e da Graduação em Publicidade e Propaganda da Universidade Federal de Pernambuco (UFPE). E-mail: k.patriota@gmail.com

3 Mestranda em Comunicação da Universidade Federal de Pernambuco (UFPE) e graduada em comunicação pela Universidade Federal de Alagoas (UFAL). Email: egbrodrigues@gmail.com. 
unificado e natural. A ideia de um mundo globalizado como um processo que, envolvendo a interação entre fatores econômicos e culturais, causa mudanças nos padrões de produção e consumo e, por sua vez, produz identidades (Woodward, 2013), traz à tona a noção de "crise de identidade", algo essencial para a discussão que se delineia neste trabalho.

Afinal, vivemos em uma época de incertezas, marcada pelo descentramento do sujeito do seu lugar no mundo social e de si mesmo. Apesar de Marx e Engels (2000) já terem apontado a modernidade como uma época em que tudo que é sólido se desmancha no ar, a peculiaridade da nossa fase, pósmoderna, é a rapidez dos fluxos comunicativos e as fragilidades das relações humanas.

Assim as sólidas bases institucionais, que um dia situaram o indivíduo e lhes deram segurança sobre seu pertencimento a determinadas comunidades, tornaram-se líquidas. Não se trata mais do mesmo mundo, nem das mesmas pessoas. A individualização se tornou uma condição pós-moderna, ocasionando a crise a qual fizemos referência. Nesse sentido, a individualização passa a dizer respeito, segundo Bauman (2008), a emancipação deste mesmo indivíduo. Com efeito, assistimos então a transformação da identidade em algo "dado", em uma "tarefa", não obstante não ser ela uma questão privada, mas socialmente produzida. Por conseguinte, como uma configuração da sociabilidade, a identidade "depende por sua vez da forma como a tarefa de individualização é enquadrada e respondida" (Bauman, 2008, p.183).

Esta "crise" é parte de um processo mais amplo de mudanças que, segundo Hall (2011), está deslocando as estruturas da sociedade "e abalando os quadros de referência que davam uma ancoragem estável aos indivíduos no mundo social" (Hall, 2011, p.07). Se antes instituições sociais como a Família, a Escola e a Igreja eram responsáveis por conduzir os indivíduos, em termos de conduta e escolhas pessoais, hoje esse papel é exercido, em grande medida, pela mídia.

Portanto, estabelecida como elemento mediador nas construções identitárias dos indivíduos, a mídia, e em especial a televisão, ancora a nossa 
paisagem cultural e é fator determinante na organização do nosso tempo social. Isso significa dizer que a maior parte de nossas representações da realidade e práticas sociais é formada a partir dos sistemas simbólicos, atualmente midiáticos, mas que outrora eram principalmente religiosos - não foi por acaso que a abordagem simbólico-cultural4 emergiu para interpretar a religião como depositária de significados culturais e que oferecia sentido e identidade à existência humana, ambos essenciais para o indivíduo e a coletividade decifrarem sua condição de vida e dominarem o seu ambiente.

Contudo, é na contemporaneidade que a mídia vem ocupando um lugar estratégico nas dinâmicas culturais, transformando, como postulam MartínBarbero e Grey (2004), sensibilidades, relações interpessoais e modos de subjetivação do sujeito. Esse sujeito, produzido no interior de formações discursivas específicas (Hall, 2013) é, a todo o tempo, convocado pela mídia a assumir determinadas posições, o que só é eficaz na medida em que haja identificação com os discursos circulantes nela (na mídia) e com o reconhecimento dos ethos resultantes das adesões dos sujeitos a certas posições discursivas.

Validamente, há uma manifesta aderência clássica nesse entendimento à Retórica de Aristóteles e que versa sobre a eficácia do discurso em persuadir, um saber extra-discursivo do enunciador (Maingueneau, 2011, p.70). Ou, em outras palavras, a potência e a força na emergência do ethos alude mais à forma de enunciação do que à materialidade discursiva do enunciado: "[...] o ethos se mostra, ele não é dito" (Maingueneau, 2011, p.71).

Exatamente nesse contexto de um ethos que se mostra como alicerce identitário para os outros e em meio a uma patente crise de identidade, surge o nosso objeto de reflexão. Um programa televisivo (The Love School) de uma

\footnotetext{
4 O principal expoente na defesa desta abordagem foi Max Weber (1864-1920), muito embora tal corrente também tenha encontrado acolhimento em Georg Simmel (18581918) e Ernst Troeltsch (1865-1923). Para Weber (1991), as ideias exercem um papel autônomo na causalidade histórica, assim sendo, a religião não poderia consistir apenas num necessário sistema de ideias ou significados, intrinsecamente ligado à vida social, mas como detentora de um estatuto próprio, relativamente independente das condições materiais e nesse caso, também dos suportes midiáticos disponíveis.
} 
igreja (Universal do Reino de Deus) que se transformou numa poderosa marca de produtos e serviços e uma apresentadora (Cristiane Cardoso) que corporifica, pelo espírito empreendedor de seus discursos midiáticos de sucesso e felicidade, como a identidade da mulher ideal (por ela chamada de Mulher V5) está relacionada ao consumo simbólico de produtos e serviços atrelados à adesão da igreja em questão.

\section{O programa The Love School e sua apresentadora}

A marca The Love School - A Escola do Amor, criada em 2011 pela Igreja Universal do Reino de Deus - IURD tem um programa televisivo como seu principal produto. Seu discurso é baseado em premissas de autoajuda e aconselhamentos bem semelhantes à reunião intitulada Terapia do Amor ${ }^{6}$, mas sem mencionar diretamente o nome da igreja. A marca possui outros produtos, como livros, revistas e cursos, sempre em complementaridade, e atua em várias plataformas midiáticas, como blogs, Facebook, Twitter e Youtube.

Os apresentadores Renato e Cristiane Cardoso, personificação da felicidade conjugal, são o rosto da "escola", trazendo sempre "ensinamentos didáticos" para o público, que eles chamam de "alunos". Mas o que não é dito é o papel da igreja por trás da marca, nem que os apresentadores são um bispo e a filha de Edir Macedo, fundador e líder maior da igreja.

Cristiane, em quem concentraremos a nossa reflexão, nasceu em 31 de outubro de 1973, no Rio de Janeiro, cinco anos antes da fundação da IURD. Aos 17 anos, em 1991, casou-se com seu primeiro namorado, Renato Cardoso, na época um jovem bispo da igreja fundada por seu pai, que conheceu em São Paulo, durante um evento da Universal, um ano antes de se casarem. Em seu blog, Cristiane relata que a época do casamento foi difícil, pois a IURD e sua família estavam sendo perseguidas por causa da compra da Rede Record, em 1989.

\footnotetext{
5 Uma referência à mulher virtuosa descrita no Antigo Testamento da Bíblia cristã.

${ }^{6}$ Culto da Igreja Universal voltado principalmente para casais.
} 
Sua carreira como evangelizadora começou cedo. Apesar de vivenciar algumas experiências em família com o trabalho de seu pai, Cristiane logo começou a atuar apenas duas semanas após seu casamento, quando partiu com o marido para Nova Iorque. O trabalho na cidade durou cerca de dois anos, quando se mudaram para Miami e ficaram por oito meses.

Cristiane conta que nesse tempo aprendeu a ser dona de casa e a conviver com outras famílias no mesmo ambiente doméstico. Posteriormente, entre moradias na África do Sul e Europa - onde abriram diversas igrejas - e uma viagem a Portugal, ela e o marido adotaram Felipe 7 , um garoto de quatro anos, já que, segundo o casal, não terem um filho biológico foi uma opção, devido à falta de tempo para se dedicarem, por completo, a um recém-nascido (The Love School em Revista, $\mathrm{n}^{0}$ 1, Maio 2013).

Cristiane conta que, justamente na época que abriram as igrejas e desenvolviam seus trabalhos missionários, percebeu que poderia ser mais que uma "ajudante" do marido e iniciou sua carreira na mídia institucional da IURD. Escreveu diversas colunas semanais voltadas para o público feminino. Seus textos foram compilados e geraram, em 2006, seu primeiro livro intitulado "Melhor do que comprar sapatos", publicado primeiramente em inglês e depois traduzido para o português, tornando-se um best-seller no Brasil. Em paralelo, Cristiane iniciou suas atividades na emissora de rádio Liberty, com o programa "Free Woman". Na tevê sua atuação começou em 2007, com o programa "Coisas de Mulher", em um canal internacional de Portugal.

Em 2008 o casal foi transferido para Houston, onde abriu a primeira igreja da cidade e depois para San Antonio, Dallas e Katy. Durante esse tempo, Cristiane fundou o projeto Godllywood, um grupo que, segundo ela, surgiu para auxiliar mulheres de diversas idades a se tornarem "verdadeiras mulheres de Deus". Logo, foram formados três subgrupos: Pré-Sisterhood (para meninas de 8 a 13 anos), Sisterhood (para jovens mulheres de 14 a 30 anos) e Mulher-V (para mulheres acima de 30 anos). O projeto angariou muitas adesões se

7 Hoje, Felipe, aos 21 anos, mora nos Estados Unidos com sua esposa e o filho. 
constituindo como um sucesso, que tem alcançado fiéis da IURD em todo o mundo, com a promoção de diversos eventos internacionais.

Apesar de não se considerar uma boa cantora, Cristiane também gravou, em 2011, uma música para a Igreja Universal, “Ah, que dia!"8, com duas versões: uma em português e outra em inglês. No mesmo ano escreveu seu segundo livro, "A Mulher V" - mais um best-seller, e foi transferida, junto com o marido, para o Brasil, onde estreou o programa The Love School - A Escola do Amor, primeiro na IURD TV, depois na Rede Record. Com o gancho no programa, o casal lançou dois novos livros "Casamento Blindado", novo best-seller para o currículo de Cristiane, e recentemente o título "120 minutos para blindar seu casamento".

Atualmente, Cristiane desenvolve trabalhos voltados principalmente para o público feminino, sejam as fiéis da igreja ou não. Junto com o marido, continua à frente da marca The Love School e promove uma gama variada de produtos e serviços, desde livros e revistas a cursos e palestras sobre o relacionamento a dois. Demonstra, claramente, ser uma das maiores líderes da Igreja Universal, apesar da instituição não permitir às mulheres o exercício do ministério pastoral.

Como personalidade midiática, Cristiane incorpora o ethos atualizado da "mulher virtuosa" (A Mulher V), definida no seu livro como "moderna à moda antiga" e ancorada na imagem do casal perfeito ${ }^{9}$ que se apresenta nos produtos e serviços da marca The Love School.

\footnotetext{
${ }^{8}$ https://www.youtube.com/watch?v=BRzTOByjUSA.

9 Embora admitam na mídia já terem tido problemas, mas que foram superados para que agora ambos tenham a missão de ajudar outras pessoas, ensinando as ferramentas que utilizaram no próprio casamento para torná-lo "vivo" e duradouro".
} 

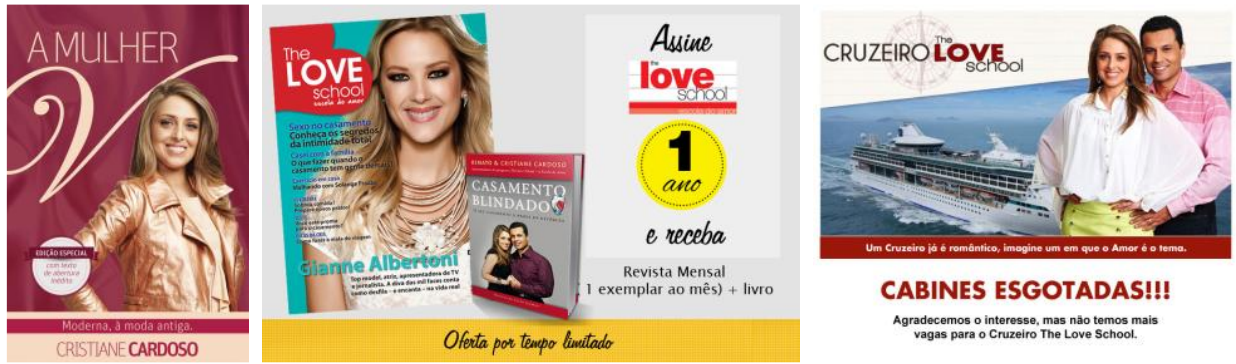

Figuras 1, 2 e 3: Na primeira imagem o livro A Mulher V, com Cristiane ilustrando a capa. Na segunda, anúncio de venda do livro Casamento Blindado com a oferta grátis da Revista The Love

School e na terceira o anúncio do Cruzeiro The Love School com as cabines esgotadas para venda.

Esse ethos, que é atualizado por Cristiane em seu livro, parece-nos determinante na construção da identidade da mulher que pode materializar o “ideal de Deus", apresentado pela IURD e baseado no livro bíblico de Provérbios, no seu capítulo 31:

O coração do seu marido está nela confiado; Ela só lhe faz bem, e não mal, todos os dias da sua vida; Busca lã e linho, e trabalha de boa vontade com suas mãos; Como o navio mercante, ela traz de longe o seu pão; Levanta-se, mesmo à noite, para dar de comer aos da casa, e distribuir a tarefa das servas; Examina uma propriedade e adquire-a; planta uma vinha com o fruto de suas mãos; Cinge os seus lombos de força, e fortalece os seus braços; Vê que é boa a sua mercadoria; e a sua lâmpada não se apaga de noite; Estende as suas mãos ao fuso, e suas mãos pegam na roca; Abre a sua mão ao pobre, e estende as suas mãos ao necessitado; Não teme a neve na sua casa, porque toda a sua família está vestida de escarlata; Faz para si cobertas de tapeçaria; seu vestido é de seda e de púrpura; Seu marido é conhecido nas portas, e assenta-se entre os anciãos da terra; Faz panos de linho fino e vendeos, e entrega cintos aos mercadores; A força e a honra são seu vestido, e se alegrará com o dia futuro; Abre a sua boca com sabedoria, e a lei da beneficência está na sua língua; Está atenta ao andamento da casa, e não come o pão da preguiça; Levantam-se seus filhos e chamam-na bem-aventurada; seu marido também, e ele a louva; Muitas filhas têm procedido virtuosamente, mas tu és, de todas, a mais excelente; Enganosa é a beleza e vã a formosura, mas a mulher que teme ao Senhor, essa sim será louvada; Dai-lhe do fruto das suas mãos, e deixe o seu próprio trabalho louvá-la nas portas (Livro de Provérbios, Bíblia online $\left.{ }^{10}\right)$.

Para que tal abordagem fique clara, neste trabalho de caráter analíticodescritivo, buscaremos refletir, através de fragmentos do programa The Love School- A Escola do Amor, veiculado na televisão pela Rede Record e pela

${ }_{10}$ Disponível em: https://www.bibliaonline.com.br/acf+nvi/pv/31. Acesso em 10.08.2014. 
IURD TV no Youtube -, e da análise do ethos de sua apresentadora em outros espaços midiáticos como as redes sociais, como a identidade da mulher ideal é construída discursivamente, ancorada nos postulados religiosos propagados pela Igreja Universal e na perceptível necessidade de consumo da sua oferta de produtos e serviços. A ideia é, portanto, apontar como o ethos de Cristiane é peremptório na construção identitária das mulheres que se relacionam com a IURD, seja das que aderem aos seus argumentos doutrinários como fiéis, ou das consumidoras de seus produtos e serviços.

\section{Ethos e identidade da Mulher V}

Maingueneau defende que o mesmo que o coenunciador não seja conhecedor de nada sobre o caráter do enunciador, a compreensão de que a fala pertence a um determinado gênero de discurso ou a certo posicionamento ideológico conduz a determinadas expectativas em relação à emergência do ethos do sujeito. (Maingueneau, 2011, p.70).

Logo, apreender a imagem da mulher ideal (chamada na IURD de mulher virtuosa), apresentada e corporificada em Cristiane Cardoso, implica na concepção de que o seu ethos, de mulher vencedora, cheia de qualidades e virtudes, bonita e feliz, determina a compreensão da realidade, insinuando a reprodução e a reiteração do jogo de imagens que a Igreja Universal constrói em favor de certas convicções e crenças, ligadas à sua teologia de resultados ${ }^{11} \mathrm{e}$ apresentadas, inicialmente, pelo fundador da instituição e, posteriormente, corporificadas por sua filha.

Esse ethos, que segundo Maingueneau (1987) considera a existência de certa representação do caráter jovial, severo, simpático etc e da corporalidade (conjunto de traços físicos) do enunciador que emite o discurso está,

\footnotetext{
${ }_{11}$ Que almeja para a terra todas as maravilhas que o pentecostalismo tradicional imaginava para o céu (FONSECA, 1998). Trata-se da Teologia da Prosperidade, que grosso modo, se fundamenta na legitimidade do fiel usufruir de uma vida abundante e próspera (em todos os sentidos que a prosperidade possa ser percebida: nos recursos materiais, na saúde do corpo, na vida familiar, amorosa e profissional), bastando, para isso, contribuir com a obra divina através do pagamento de dízimos e ofertas e professar a vitória como testemunhante do agir de Deus. Assim, os "resultados" poderão ser sentidos.
} 
necessariamente, articulado às antecipações daquilo que o co-enunciador constrói no processo de interação com o enunciador. Para o autor, concepção, caráter e corporalidade são totalmente inseparáveis, articulam-se e apoiam-se sobre estereótipos padronizados na coletividade na qual é produzida a enunciação.

Para a IURD, segundo o seu líder máximo, o Bispo Edir Macedo, o sonho da "Mulher de Deus" é parir filhos de Deus e servir como instrumento do Espírito Santo para auxiliar o homem em sua jornada na Terra. Portanto, ela deve ser casada e ter sobre si a responsabilidade pelo cuidado da casa - o que envolve o marido e os filhos. Assim, a posição defendida no seio da Universal é que "a mulher foi criada com a finalidade específica de auxiliar o homem na procriação, na educação dos filhos e na administração da casa, além do aspecto afetivo" (Macedo, 2007, p.18).

No "governo" do lar "ideal", postulado pela IURD, à mulher cabe a tarefa de gerenciamento e cuidados práticos, enquanto para o homem é destinado o sustento da casa - o que não impede que a mulher possa trabalhar fora também, desde que não esqueça suas responsabilidades domésticas (que são maiores que as do marido) e entenda a dimensão da submissão ensinada na Bíblia. A igreja alerta que uma união jamais dará certo se essa visão de submissão for perdida, principalmente nos casos em que a mulher tenha renda superior a do marido, deixando-o numa posição desfavorável: "Imaginemos, por exemplo, uma mulher de mais idade, mais experiência e cultura, ou que esteja tecnicamente em um nível superior ao do marido. De que maneira ela se submeterá à liderança dele, na vida em comum?” (Macedo, 2007, p.19).

Não é por acaso que a submissão é um ponto importante em toda discussão da IURD sobre o modelo de comportamento feminino. Para a denominação, submissão significa "prazer em servir por amor", consequentemente, a mulher deve ser submissa ao seu marido por amor e com prazer - e não o contrário, pois tal abnegação é fruto do "mover" do Espírito Santo. Por isso deve ser algo natural. Se o homem não é cristão, as mulheres são aconselhadas a trata-lo com carinho para que se converta, e isso exige paciência 
e aguentar em silêncio, pois o temor a Deus e a submissão ao marido são prérequisitos de uma mulher virtuosa. Criticá-lo e atormentá-lo com cobranças são atitudes inadmissíveis. "A mulher temente a Deus e submissa ao seu marido sabe "aturar" seus erros, porque tem consciência de que ele ainda não teve um encontro com Deus" (Macedo, 2007, p.51).

Nesse contexto é importante que retornemos às peculiaridades do conceito de ethos. Como os enunciados são produtos de uma enunciação que implica numa cena, e como toda fala procede de um enunciador real, encarnado - mesmo quando escrito, e não falado, a fala obrigatoriamente é sustentada por uma voz, que, segundo Maingueneau (1988, p.95), é: “a voz de um sujeito situado para além do texto".

O ethos que emerge de Cristiane, através da sua corporificação da mulher virtuosa que salta das páginas da Bíblia, alude à existência de um controle tácito do corpo, apreendido por meio de um comportamento global. Ela, de forma constante, se coloca fisicamente atrás do marido, que comanda as falas e lhe confere algumas participações no falar. Ele conduz o discurso e permite que Cristiane, em dueto com ele, se pronuncie nas aparições da marca The Love School, muitas vezes ele segura o microfone próximo à boca dela, conferindo-lhe a possibilidade do "dizer".

Isso ocorre mesmo que a mulher $\mathrm{V}$, como ressalta Cristiane na atualização do texto bíblico, seja "forte" pela força espiritual, pela força de influência e pela força da sua submissão ao marido. Mas também porque dá conta de tudo. Ela cuida da casa e de todas as necessidades domésticas. Sabe cozinhar, se cuida, cuida dos filhos, provê segurança para o marido e ainda desenvolve um trabalho em paralelo. O ethos de Cristiane desponta em muitos espaços para corroborar com tal visão, mesmo que esta seja "atualizada" na "mulher moderna", que conta (e deve contar) com a ajuda de outras pessoas para desempenhar o seu papel de mulher virtuosa:

Para fazer tudo que queremos fazer, precisamos da ajuda de outras pessoas. Infelizmente, muitas mulheres querem dar conta de tudo sem pedir ajuda, pensam que se tiverem que pedir ajuda estarão sendo fracas e até perdendo o controle de suas responsabilidades... no fundo, são egoístas. Querem fazer tudo e ter controle de tudo. Só que 
não se dão conta de que quanto mais fazem, mais deixam a desejar, já que ninguém consegue dar conta de tudo sozinho! $\mathrm{E}$ aí acabam sendo estressadas, impacientes, ignorantes, rudes, e outras coisas. E pior, se fazem tão indispensáveis que o dia em que ficarem doentes, o mundo literalmente para. Amigas, temos que aprender a compartilhar nossos afazeres, confiar nas pessoas, mesmo que elas inicialmente não façam a coisa do nosso jeito. Faz parte do perfil de uma mulher sábia ensinar e fazer discípulos... Lembram-se da Mulher Virtuosa de Provérbios 31? (Blog de Cristiane Cardoso, publicado em 18/o6/2014).

A mulher virtuosa está sempre em cena e ganha materialidade na imagem de Cristiane, que encena suas falas de acordo com o que se espera do espaço onde estas são proferidas. Para ampliar o campo da análise, observamos o programa The Love School. Nele, por exemplo, a submissão sofre modalizações discursivas, pois se dirige a um target que não é totalmente religioso e nem composto exclusivamente de fiéis da IURD. O livro bíblico de Provérbios não é evocado. O programa é classificado na emissora Record como de "entretenimento" e tem lógicas de produção idênticas a de outros programas semelhantes que visam alcançar diversificados públicos. No que diz respeito aos conteúdos, os apresentadores (Cristiane e seu marido) sempre dão opiniões de cunho ideológico, demarcando, de forma modalizada, os papéis de homens e mulheres no dia a dia, mas sem falar de Deus ou da igreja. A todo tempo mostram, através de histórias, gestos e até mesmo na maneira de falar - em uma sincronia ensaiada - a "química” entre os dois.

Assim, vemos a constituição do ethos de Cristiane como a Mulher V emergir como detentor de uma dupla vinculação: com a enunciação em si e com as representações que o público constrói sobre ela e que antecede a sua própria fala. As duas vinculações são, portanto, discursivas e pré-discursivas. Nesse sentido, Maingueneau (2011) postula que há discursos e situações em que o coenunciador não possui elementos prévios que possibilitem a representação do enunciador, mas quando os enunciadores “ocupam constantemente a cena midiática, são associados a ethos que cada enunciação pode confirmar ou infirmar". (Maingueneau, 2011, p.70).

É justamente este o caso de Cristiane. Aspectos que ela faz questão de ressaltar em suas falas no programa The Love School e que versam sobre a mulher virtuosa do livro bíblico de Provérbios, são atualizados e exibidos. 
Denotam como a sua submissão ao marido ajudou na construção da felicidade do casal. O tema controverso da submissão, mesmo que discursivamente modalizado, igualmente alicerça o seu ethos e aflora no caráter e na corporalidade dela como fiadora, sempre em feliz submissão ao cônjuge. Apoiase, então, sobre um conjunto difuso de representações sociais, valorizadas ou desvalorizadas, de estereótipos sobre os quais a enunciação se sustenta e, por sua vez, contribui para reforçar ou transformar (Maingueneau, 2011, p.72) a identidade feminina na IURD.

\section{Consumo e construção da identidade feminina na IURD}

Muito se tem debatido e escrito sobre o papel da mulher na sociedade moderna. Discussões exaustivas se ancoram na temática do gênero e abrem espaço tanto para visões convergentes quanto divergentes. Não obstante, o fato que não se pode negar é que há uma clara preocupação em todos os campos para demarcar o lugar que a mulher ocupa, ou deve ocupar, na contemporaneidade. Com as instituições religiosas, abarrotadas de mulheres (já que estas se constituem como o maior contingente de fiéis), não poderia ser diferente.

De forma geral, tais instituições se dividem acerca dos limites e esferas da atuação feminina, muito embora utilizem as Escrituras e os textos fundantes como o ponto de partida norteador e doutrinário. Contudo, para este artigo, cuja ancoragem se deu num recorte bem específico, numa determinada visão e numa mulher em particular: a Igreja Universal do Reino de Deus - IURD e a filha do seu fundador, Cristiane Cardoso e suas aparições midiáticas, analisamos como o seu ethos de "mulher ideal" se articula com o consumo para fazer emergir o padrão identitário para mulher na IURD.

Como já pontuamos anteriormente, no discurso de Cristiane, o ethos se manifesta na própria enunciação da IURD (vide as falas do fundador Edir Macedo) e igualmente nos seus discursos no The Love School, mesmo que estes pareçam "desvinculados" da Universal, tão somente porque a sua fala "encarna" as peculiaridades que normalmente são assimiladas ao comportamento dos vencedores, que aderem à Teologia da Prosperidade - que sustenta 
doutrinariamente a instituição. Nesse sentido, o ethos pré-discursivo de Cristiane, amplamente fincado na sociabilidade dela: como filha do Bispo Edir Macedo, escritora, bem casada, "filhinha do papai" ${ }^{2}$, bem sucedida, vencedora, empreendedora, apresentadora de tevê, colunista de rádio etc, atua como um catalizador da exterioridade ao qual a autoria deve se remeter. Poderíamos esmiuçar esta lógica a partir das atitudes desencadeadas pela sua fala nos programas, como no exemplo a seguir:

Não se deprima por estar solteira. Não enxergue seu
status atual como algo negativo, e sim como uma
preparação. Você está se preparando para um futuro
relacionamento feliz. (Cristiane Cardoso, Programa The
Love School "Agora me valorizo", exibido em
o7.06.2014).

Com um discurso bastante direto, ela enuncia diretrizes para todas as mulheres porque o seu ethos encarna o ideal almejado por todas. Ela é feliz no casamento e na vida em geral. Assim, a identidade é moldada a partir dos posicionamentos que ela assume em diferentes campos, nos quais são exercidos diferentes graus de autonomia: mulher, dona de casa, esposa, mãe, escritora, colunista, apresentadora. Cada sistema simbólico possui um habitus próprio, estruturado em relações desiguais de poder, que são estabelecidas conforme a própria estrutura do campo. Isso quer dizer que Cristiane é solicitada a agir de maneiras diferentes a depender do campo de atuação, fazendo com que seu ethos corporifique conjuntamente diferentes identidades que se influenciam mutuamente, ou até mesmo que entram em conflito. Contudo, esse ethos é determinante para que a identidade feminina na IURD se constitua relacionalmente, no caso em questão, no consumo dos bens simbólicos ligados ao ethos da Mulher V (beleza, juventude, vitória, sucesso, empreendedorismo, felicidade) e dos bens comercializados (livros, palestras, revistas, cruzeiros do The Love School, aulas, roupas e acessórios, entre outros).

Nesse caso, o ethos da Mulher V materializada em Cristiane é um pontochave para se pensar como o discurso opera na dimensão subjetiva dos indivíduos, através do duplo processo de identificação e projeção, ocasionado

${ }^{12}$ Como a própria Cristiane se nomeou em um dos textos do seu blog. 
principalmente pelo hibridismo entre gêneros. Hoje podemos ver como entretenimento, melodrama e religioso, por exemplo, são gêneros que se imbricam com "naturalidade" e proporcionam formas peculiares de discursos religiosos-midiáticos, como são alguns programas da Igreja Universal do Reino de Deus que, nas últimas duas décadas, tem retrabalhado seu discurso midiático de maneira a se adequar às "novas" demandas contemporâneas dos potenciais clientes religiosos.

É justamente nesse contexto que concordamos com Campbell (2006, p.50) quando argumenta que "o senso de identidade de um indivíduo não é mais claramente determinado, como já foi, por sua filiação a determinada classe ou status de certos grupos". Mesmo aceitando a tese que o consumismo é um meio fundamental para os indivíduos construírem suas identidades, o autor contesta a ideia de que na contemporaneidade não haja um conceito fixo do self. Pelo contrário: "longe se exacerbar a "crise de identidade", [o consumo] é, na verdade, a principal atividade pela qual os indivíduos geralmente resolvem esse dilema" (Campbell, 2006, p.51, grifo nosso).

Para Barbosa (2004), é através do consumo que conseguimos construir nossas identidades e combater nosso sentimento de insegurança ontológica. Mas o que isso tem a ver com a religião? O que tem a ver com a construção identitária da mulher na IURD? Se pensarmos o consumo como uma dimensão expressiva de auto reconhecimento, que diz respeito, nas palavras de García Canclini (2010), a um processo sociocultural de apropriação e uso de bens simbólicos e materiais que, deve-se salientar, começa antes e termina muito depois da compra - nos referindo especificamente ao consumo de objetos - essa aproximação se torna mais visível. Embora possamos considerar o ato em si individual, chamamos atenção para sua qualidade social, pois como meio de construir e afirmar identidades, ele permite o acesso a determinados grupos, através de processos de inclusão e exclusão. Vejamos os depoimentos de algumas mulheres que consumiram o livro "A Mulher V":

Fiz algumas mudanças no meu visual, mas sentia que faltava algo. $\mathrm{O}$ livro "A Mulher V" veio como última gota - aquela que transborda, mas só que dessa vez tudo transbordou para melhor. Depois de ler o livro da senhora mudei algumas atitudes que me afastavam do 
Senhor, e mesmo com algumas tribulações não tenho reações agressivas, e penso como agiria uma "mulher V"; e aí o Espírito Santo me dá a certeza de que sou capaz.(LPP, 2014).

Sempre gostei de usar lingerie sexy, mas esta semana fui surpreendida, e me senti incomodada no trabalho por está usando o famoso fio dental. Então pensei no capítulo do livro "A Mulher V" se valoriza - não fica usando roupas sensuais que desperta desejos masculinos. Esse fato ocorreu há 20 dias, e desde então não consigo usar mais esse tipo de lingerie. Estou me vigiando na maneira de agir e falar. (RGS, 2014).

O livro "A Mulher V" fala da mulher virtuosa que não era perfeita, mas era temente a Deus. A mulher virtuosa é comparada a jóia mais preciosa "o rubi"; e qualquer uma pode ser virtuosa nos dias de hoje, desde que nos tornemos exemplo de sabedoria. Com a leitura do livro descobrir [sic] que a mulher virtuosa não é preguiçosa, não gosta de fofoca, se cuida, se valoriza, além de ser especial. Sua mudança é de dentro para fora, e você pode torna-se linda, porque tem o caráter de Deus. A leitura e o mês "Rush Sisterhood" me ajudaram a descobrir a importância das tarefas de casa, do estudo, enfim me tornei mais habilidosa, e isso fez muita diferença, enfim o livro mudou a minha vida. (SFH, 2014).

Nesse sentido, pode-se afirmar que a esfera religiosa (pelo "agir de Deus”) e a do consumo (pela compra do livro), por exemplo, se cruzam e se complementam. Não que essa seja uma relação nova, pelo contrário, mas muito mais nítida por causa do importante papel desempenhado pela mídia nas dinâmicas sociais das instituições religiosas, especialmente das igrejas neopentecostais, que têm a Igreja Universal como o seu melhor exemplo.

Nesse contexto o ethos da Mulher V, materializado em Cristiane, não se manifesta no discurso apenas como estatuto ou papel, mas igualmente como uma voz e um corpo enunciante que fornece as diretrizes para que a identidade feminina iurdiana possa aflorar. Trata-se de uma incorporação tríplice, que institui uma relação mútua com a sua própria enunciação: a pressupõe e a valida progressivamente. Voz (as falas de Cristiane), corpo (a beleza e a jovialidade encarnada nela) e caráter (resultados palpáveis da felicidade e sucessos exibidos) conformam a origem enunciativa do discurso em quaisquer dos espaços que o disponibilizam (blog, TV, redes sociais e palestras ao vivo), numa instância subjetiva encarnada que exerce o papel de fiador. Não é por acaso que Maigueneau (2011) evidencia a existência de uma vocalidade específica, de um tom para versar sobre a voz enunciativa e no que faz referência 
ao corpo e ao caráter. $\mathrm{O}$ autor explica que o discurso recupera um conjunto de determinações físicas e psicológicas atribuídas pelas representações coletivas à personagem do orador.

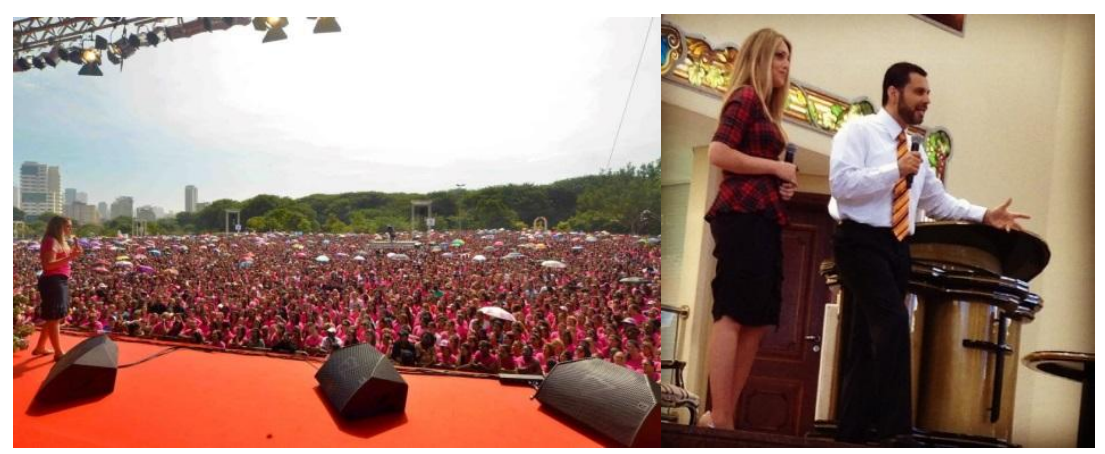

Figuras 4 e 5: Na primeira imagem, Cristiane faz uma palestra motivacional em um evento organizado pelo IURD no Dia Internacional da Mulher. Na segunda, ela se coloca ao lado do esposo, Renato Cardoso, em uma palestra na Terapia do Amor.

Vemos isso em todo o jogo de cena de Cristiane, seja quando fala "sozinha" ou em seu "dueto" com o marido bispo, mesmo que o discurso silencie o pertencimento à IURD e não explicite os postulados religiosos que o alicerçam. Os dizeres são mobilizados num quadro enunciativo propício e peculiar à coletividade da Igreja, nas determinações físicas e psicológicas inerentes às representações coletivas da filha do líder máximo da denominação e mulher de um bispo bem sucedido. Da moça, que mesmo sendo "bem criada"13, sofreu lutas e dores, mas venceu e conquistou o papel de mulher virtuosa - papel este que hoje ela diz ser disponível a todas que desejarem, basta que consumam o que é ofertado (livros, palestras, cruzeiros em navios, discursos midiáticos instrutivos etc).

\section{Considerações finais}

Discursivamente a identidade feminina da IURD se atrela, irrevogavelmente, ao ethos que Cristiane expõe, enquanto "reproduz", "interpreta" e "atualiza" a fala de Deus, na apresentação da Mulher Virtuosa descrita no livro bíblico de Provérbios, no seu capítulo 31. Nesse sentido, a IURD, de forma não explícita, se representa e se mantém como uma instituição de privilégio e detentora da legitimação na enunciação de uma porta-voz de uma

${ }_{13}$ Como Cristiane se define em um texto no seu blog. 
verdade inquestionável, pois ela encarna o ideal de Deus, propagado pelo fundador da igreja, em diálogo com diversos trechos bíblicos ${ }^{14}$ :

Ela teme ao Senhor, e esse temor faz com que veja o marido como se fosse o Senhor Jesus, mesmo que ele seja incrédulo. (...) (Provérbios 31:30).

Ela é sabia; por isso, fala pouco ou só mesmo o necessário. Quando a pessoa fala muito é porque é egoísta, e sempre quer impor aos outros as suas ideias e pensamentos. (...) (Provérbios 13:3).

Ela é discreta. Nunca procura chamar a atenção dos outros para si. O seu comportamento é contrário ao das mulheres do mundo. A sua fala é suave, os seus vestidos são discretos. O seu rosto pode ser maquiado, mas não "mascarado"; o seu cabelo é penteado, mas não de forma exótica (...) (Provérbios 11.22).

Ela é virtuosa. A mulher virtuosa é aquela que procura cuidar muito mais do seu coração do que do seu corpo. Tem, como fragrância no seu corpo, a plenitude da presença do Espírito Santo. (...) (2 Coríntios 2:15).

Ela é forte. Não se abate diante das dificuldades. Pelo contrário, quando os momentos difíceis acontecem, surge com a determinação de mulher de Deus. (...)(Provérbios 31.25).

Ela é de Fé. A mulher de Fé é aquela que vê nas dificuldades apenas novas oportunidades. Como dona-de-casa, sabe fazer do limão uma boa limonada! Estimula a Fé do seu marido com palavras de ânimo e coragem. (...) (Provérbios 31:11).

Ela é trabalhadeira. A mulher de Deus nunca é preguiçosa, porque tem prazer em cuidar dos afazeres de casa de tal forma que, quando o seu marido chega à casa, tudo estará em ordem. Ela não espera que os outros façam aquilo que é de sua competência. (Provérbios 31:15 e 27)

Ela é fiel. A mulher de Deus não é fiel apenas ao seu marido, mas também à sua igreja. Sua fidelidade se faz transparecer no serviço da obra de Deus. (...) (Lucas 8:1-3).

Ela é sensata. A mulher de Deus sabe ser cuidadosa com suas palavras, especialmente quando o seu marido é incrédulo. Os lamentos e as reclamações nunca surtem bom efeito nos ouvidos de quem os ouve. Se é sensata, sabe como contornar uma situação desagradável, ao invés de ficar reclamando todo o tempo. (...) (Provérbios 18:21).

Ela tem bons olhos. A mulher de Deus procura ver as demais pessoas como Deus as vê. É verdade que há pessoas más e que é difícil vê-las com bons olhos, mas porque ela é de Deus os seus olhos sempre procuram ver o lado bom daquelas pessoas (...) (Mateus 6:22-23). (Macedo, 1997, p.81-85, grifos nossos)

${ }^{14} \mathrm{O}$ texto foi escrito por Edir Macedo e, ao final, ele faz referência ao livro bíblico que o inspirou na sistematização que descrever os "mandamentos da mulher de Deus". 
A partir da emergência desse ethos (como descrito pelo fundador da IURD) em Cristiane, se instaura a constituição de um não-eu que se torna eu na medida em que sua enunciadora, no caso analisado, a filha do líder da igreja, "acolhe" o que é dito pelo outro (que é Deus) para a real legitimação do seu discurso. E mesmo que no seu discurso midiático, em diversos momentos, ocorra um claro afastamento da identificação religiosa, o modo de presença dela nos espaços por onde trafega instaura uma relação dialógico-interacional com a finalidade de perpetuar um modo discursivo de falar sobre Deus e as verdades divinas enquanto ajuda a construir a identidade feminina esperada na denominação.
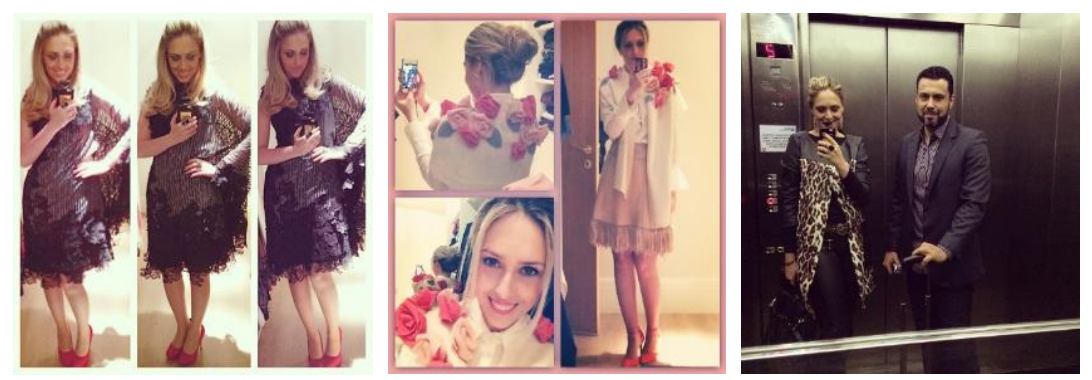

Figuras 6, 7 e 8: Imagens publicadas no Instagram e perfil pessoal de Cristiane no Facebook. A primeira se refere ao "look do dia" para a inauguração do Templo de Salomão, a segunda de uma roupa que ela ganhou de uma grife e a terceira do "look" do casal para a Terapia do Amor.

Assim, o The Love School e todos os seus desdobramentos para estimular o consumo de bens, sejam eles simbólicos ou não, é uma das marcas que dá a palavra aos representantes da IURD, cuja cenografia é imposta de forma imediata quando os potenciais fiéis são atingidos e aceitam o lugar que lhes é consignado nesta cenografia, ao mesmo tempo em que buscam moldarem-se à identidade proposta.

O programa, por conseguinte, acaba por transformar-se em uma estratégia proselitista na qual é apresentada a IURD sob a ótica do cotidiano, na atualização "velada" (pois não há nada de explícito nisso) de textos de cunho religioso, na ponte com o dia-a-dia das pessoas e no viés da própria cena enunciativa relatada da Bíblia ao apresentar a Mulher V que Cristiane materializa. Desta forma, é possível enxergar o objetivo da IURD de reiterar abordagens práticas para uma vida segundo a abundância de Deus e da Teologia 
da Prosperidade, repleta de signos terrenos de consumo e felicidade, ao exibir uma identidade mais do que "desejável".

\section{Referências}

BARBOSA, Lívia. Sociedade de Consumo. Rio de Janeiro: Jorge Zahar, 2004.

BAUMAN, Zygmunt. A sociedade individualizada - vidas contadas e histórias vividas. Rio de Janeiro: Zahar, 2008.

CAMPBELL, Colin. Eu compro, logo sei que existo: as bases metafísicas do consumismo moderno. In: BARBOSA, Lívia; CAMPBELL, Colin (org). Cultura, consumo e identidade. Rio de Janeiro: Editora FGV, 2006.

CANCLINI, Nestór. Consumidores e Cidadãos. $8^{\mathrm{a}}$ Ed. Rio de Janeiro: Editora UFRJ, 2010.

FONSECA, Alexandre. Nova Era Evangélica, Confissão Positiva e o Crescimento dos Sem Religião. Trabalho apresentado no seminário temático STo2 Nova Era e o complexo alternativo. Anais... VIII Jornadas sobre Alternativas Religiosas na América Latina, São Paulo, 22 a 25 de setembro de 1998.

HALL, Stuart. A identidade cultural na pós-modernidade. $11^{\text {a }}$ ed. Rio de Janeiro: DP\&A, 2011.

. Quem precisa da identidade? In: SILVA, Tomaz Tadeu (org). Identidade e diferença: a perspectiva dos Estudos Culturais. $13^{\text {a }}$ ed. Petrópolis, RJ: Editora Vozes, p.103-133, 2013.

MACEDO, Edir. O Perfil da Mulher de Deus. $2^{\text {a }}$ edição. Rio de Janeiro: Universal, 1997.

$$
2007 .
$$

O Perfil da Família de Deus. Rio de Janeiro: Unipro,

MAINGUENEAU, Dominique. Ethos, cenografia e incorporação. In: Ruth Amossy (Org.). Imagens de si no discurso: a construção do ethos. São Paulo: Contexto, 2011. p. 69-92.

MARTÍN-BARBERO, Jesús; GREY, Germán. Os exercícios do ver: hegemonia audiovisual e ficção televisiva. $2^{\mathrm{a}}$ ed. São Paulo: Editora Senac São Paulo, 2004.

$M A R X$, Karl; ENGELS, Friedrich. O manifesto do partido comunista. São Paulo: Editora Martin Claret LTDA, 2000.

WOODWARD, Kathryn. Identidade e diferença: uma introdução teórica e conceitual. In: SILVA, Tomaz Tadeu (org). Identidade e diferença: a perspectiva dos Estudos Culturais. $13^{\text {a }}$ ed. Petrópolis, RJ: Editora Vozes 103-133, p.7-72.

The Love School em revista. Ano 1, $\mathrm{N}^{\circ}$ 1, Maio 2013. Editora Duetto. 